\title{
IDENTIFIKASI PENGAWAKAN KAPAL NEGARA DALAM PERSPEKTIF PERATURAN PENGAWAKAN KAPAL NEGARA DI INDONESIA
}

\author{
Irwan $^{1)}$, Ahmad Fauzi²), Meti Kendek ${ }^{3)}$, Mahbub Arfah ${ }^{4)}$ \\ Politeknik IImu Pelayaran Makassar \\ Jalan Tentara Pelajar No. 173 Makassar, Kode pos. 90172 \\ Telp. (0411) 3616975; Fax (0411) 3628732 \\ E-mail: pipmks@pipmakassar.com
}

\begin{abstract}
ABSTRAK
Mengungkapkan peranan kapal negara, sekaligus memberi gambaran besarnya jumlah armada dan besarnya jumlah anak buah kapal yang dibutuhkan kapal negara agar dapat dilayarkan sesuai standar pengawakan. Tujuan penelitian mengetahui kesesuaian sertifikasi keahlian dan keterampilan anak buah kapal negara dengan peraturan tentang pengawakan kapal negara yang berlaku. Penelitian ini menggunakan analisis kualitatif deskriptif, indikator pengamatan yang dinyatakan dalam perhitungan persentase (\%), yakni persentase jumlah anak buah kapal negara pada level Perwira yang memiliki sertifikat kehlian dan keterampilan yang sesuai Peraturan Direktur Jenderal Perhubungan Laut. Hasilnya menunjukkan jumlah kapal negara yang saat ini dioperasikan oleh Kementerian terkait hanya $50 \%$ dari jumlah seluruh kapal yang dibutuhkan. Kondisi ini tentu berdampak pada kinerja layanan kapal negara. Analisis data menunjukkan bahwa $39.3 \%$ anak buah kapal negara yang memiliki sertifikat kompetensi dan profesiensi yang sesuai dengan aturan sertifikasi pada Peraturan Direktur Jenderal Perhubungan Laut Nomor HK.103/3/13/DJPL-15, Kondisi ini sekaligus mengindikasikan besarnya kebutuhan anak buah kapal negara untuk mengikuti pendidikan dan pelatihan yang sesuai dengan kapal yang operasikannya.
\end{abstract}

Kata kunci: Kapal Negara, Sertifikasi, Pengawakan. 


\section{Latar Belakang}

Salah satu strategi percepatan dan perluasan pembangunan ekonomi nasional adalah dengan mengedepankan penguatan konektifitas antar pulau terutama pulau-pulau terluar. Konektifitas ini hanya bias terwujud apabila transportasi laut di negara kepulauan terus diperankan secara signifikan. Untuk mewujudkan konektifitas tersebut maka transporasi laut yang selanjutnya dalam penelitian ini berorinetasi pada kapal Negara harus dilaksanakan dengan aman dan nyaman. Persoalan bagi Indonesia tidak sekedar bagaimana mengembangkan angkutan laut yang kompetitif, tetapi juga bagaimana menyelenggarakan angkutan laut yang memenuhi standar pengawakan, keamanan dan keselamatan pelayaran sesuai peraturan pengawakan yang berlaku.

Sejak tahun 2015 hingga saaat ini, Direktorat Jenderal Perhubungan Laut telah membangun 20 unit Kapal Kenavigasian, termasuk diantaranya 2 (dua) unit Kapal Induk Perambuan yang baru saja diluncurkan oleh Galangan Kapal PT. Dumas Tanjung Perak Shipyard. Kegiatan pembangunan kapal tersebut menunjukkan keseriusan pemerintah dalam meningkatkan jumlah armada kapal negara kenavigasian yang saat ini kondisinya sudah tua. Diperlukan penambahan armada kapal agar tugas kenavigasian dapat dilaksanakan secara optimal di seluruh wilayah perairan Indonesia.

Kapal Induk Perambuan yang dibangun akan mampu memperkuat armada kapal kenavigasian serta dapat meningkatkan keandalan Sarana Bantu Navigasi Pelayaran (SBNP) demi mendukung terciptanya keselamatan dan keamanan pelayaran di perairan Indonesia.Disamping Direktorat Kenavigasian, Kementerian Keuangan Bea dan Cukai juga membangun sembilan unit kapaljenis Fast Patrol Boat kegalangan PT Daya Radar Utama untuk memperkuat armada patroli Bea dan Cukai disejumlah daerah di Indonesia.

Kapal negara memegang posisi penting kapal negara sekaligus mengungkapkan besarnya jumlah armada yang juga berarti besarnya 
jumlah awak kapal yang dibutuhkan agar kapal negara tersebut dapat dilayarkan sesuai standar pengawakan.

Penyiapan awak kapal yang mengoperasikan kapal negara menjadi hal yang sangat penting.Awak kapal harus disiapkan sejalan dengan proses pembangunan kapal yang saat ini jumlahnya mencapai 180 unit sampai tahun2019. Kapal negara yang dibangun tersebut harus diawaki dan dioperasikan oleh awak kapal yang professional dan memenuhi standard sertifikat sesuai ketentuan.

Kemeterian Perhubungan melalui Badan Pengembangan Sumber Daya Manusia Perhubungan (BPSDMP) khususnya Pusat Pengembangan SDM Perhubungan Laut (PPSDM Hubla) memegang peran yang sangat penting dalam upaya menciptakan sumber daya manusia berkualitas dibidang transportasi laut. Untuk pengawakan kapal, PPSDM Hubla telah melaksanakan Diklat Pelayaran pada semua jenjang termasuk Diklat Keterampilan Pelaut (DKP) sebagai upaya mencetak SDM pelayaran.

Pada tanggal 30 Maret 2017, Kementerian Keuangan, Direktorat Jenderal Bea dan Cukai bersama Politeknik IImu Pelayaran Makassar menandatangani Perjanjian Kerjasama Diklat Basic Safety Training bagi pegawai Direktorat Jenderal Bea dan Cukai. Diklat tersebut diikuti30 orang yang selanjutnya akan ditempatkan pada kapal yang dioperasikan Direktorat Jenderal Bea dan Cukai. Diklat tersebut telah dilaksanakan namun menggunakan kurikukulum Diklat kapal niaga dan bukan kurikulumm Diklat kapal negara. Tidak ada permintaan mengenai pelatihan awak kapal negara kepada pihak penyelenggara. Hal ini belum sejalan dengan Peraturan Direktur Jenderal Perhubungan Laut Nomor 103/3/13/DJPL-15 Tentang Sertifikasi Keahlian dan Keterampilan Awak Kapal negara. Penelitian ini menganalisa bagaimana gambaran kapal negara di Indonesia saat ini dan bagaimana kesesuaian sertifikat awak kapal negara dengan peraturan Sertifikasi Keahlian dan Keterampilan 
Awak Kapal negara khusunya kapal patroli pangkalan Kesatuan Penjagaan Laut Dan Pantai (KPLP).

\section{Kapal Negara}

Salah satu tugas utama pelayaran kapal negara adalah menyediaan layanan kepada masyarakat sesuai standar layanan yang aman dan nyaman. Sikap mental melayani dengan tetap menerapkan standar keselamatan yang tinggi harus terus ditingkatkan. Aparatur pemerintah yang bertugas sebagai awak kapal negara harus dapat menjadi contoh dan sekaligus memantau pelaksanaan regulasi terutama terkait keselamatan pelayaran. Awak kapal negara harus dipersiapkan secara khusus dengan program dan kurikulum pendidikan yang khusus pula agar tugas dan fungsi sebagai awak kapal negara dan penegak peraturan dapat dilaksanakan dengan baik.

Terdapat 3 kementerian yang mengoperasikan kapal negara yaitu: Kementerian Perhubungan, Kementerian Keuangan (Direktorat Bea dan Cukai) dan Kementerian HAM (Hak Azazi Manusia). Karena terdapat fungsi yang berbeda antar kapal niaga dengan kapal negara maka dalam undang-undang dan peraturan terdapat pasal dan ayat yang secara khusus mengatur pengawakan kapal negara.

\section{Perundang-Undangan}

Dalam Undang-Undang Nomor 17 Tahun 2008 Tentang Pelayaran, pasal 1 angka 38, dinyatakan bahwa: Kapal negara adalah kapal milik negara digunakan oleh instansi pemerintah tertentu yang diberi fungsi dan kewenangan sesuai dengan ketentuan peraturan perundangundangan untuk menegakkan hukum serta tugas-tugas Pemerintah lainnya. Selanjutnya untuk mendidik dan melatih awak kapal yang mengoperasikan kapal niaga maka telah diberlakukan Peraturan Menteri Perhubungan Republik Indonesia Nomor PM 70 Tahun 2013 Tentang Pendidikan dan Pelatihan, Sertifikasi Serta Dinas Jaga Pelaut. Dalam pasal 54 peraturan tersebut diatur: 
1. Pelatihan khusus untuk keahlian dan/atau keterampilan yang diperlukan bagi nakhoda, perwira, dan rating serta personil lainnya pada kapal-kapal tugas/operasi tertentu dapat diselenggarakan oleh Badan Pengembangan Sumber Daya Manusia Perhubungan berdasarkan kebutuhan kompetensi yang dipersyaratkan oleh Direktur Jenderal.

2. Pelatihan khusus untuk keahlian dan/atau keterampilan yang diperlukan bagi nakhoda, perwira, dan rating serta personil lainnya sebagaimana dimaksud pada ayat (1) antara lain:

a. pelatihan khusus untuk kapal negara ;

b. pelatihan khusus untuk petugas pandu; dan

c. pelatihan khusus untuk kapal penunjang operasi lepas pantai (offshore supply vessel).

3. Ketentuan lebih lanjut mengenai pelatihan khusus sebagaimana dimaksud pada ayat (1) diatur dengan Peraturan Direktur Jenderal.

Peraturan Menteri khususnya nomor 2 bagian a tersebut di atas menyatakan keharusan bagi awak kapal yang mengoperasikan kapal negara untuk mengikuti Diklat yang dilaksanakan khusus untuk awak kapal negara. Pada pasal 54 di atas juga menunjukkan bahwa pemilik sertifikat awak kapal negara tidak memenuhi syarat untuk bertugas sebagai awak kapal niaga. Sebaliknya sertifikat kapal negara dapat digunakan untuk pengawakan kapal niaga jika telah memiliki masa layar 10 tahun. Peraturan Direktur Jenderal Perhubungan Laut Nomor HK.103/3/13/DJPL-15 Pasal 6 diatur bahwa: Pemilik sertifikat keahlian kapal negara dapat disetarakan dengan sertifikat keahlian niaga setelah memiliki pengalamal berlayar sekurang-kurangnya 10 (sepuluh) tahun yang dibuktikan dengan surat keterangan masa layar dari instansi terkait dan menyelesaikan diklat yang ditetapkan kemudian oleh Direktur Jenderal. 


\section{Pengoperasian Kapal Negara}

Kementerian Perhubungan telah meresmikan 16 kapal yang diharapkan dapat meningkatkan konektifitas antar wilayah dan meningkatkan pemerataan pembangunan nasional yang pada akhirnya berdampak pada tingkat perekonomian masyarakat baik di wilayah barat maupun wilayah timur Indonesia. Pembangunan infrastruktur dan pengembangan potensi kemaritiman Indonesia merupakan bentuk kehadiran negara dan keseriusan pemerintah dalam mewujudkan program Nawacita untuk menjadikan Indonesia sebagai poros maritim dunia. Gambaran dari 16 unit kapal Kementerian Perhubungan pendukung program Tol Laut yang diresmikan oleh Presiden RI adalah sebagai berikut:

a. 1 unit kapal perintis ukuran GT 2000 yang diberi nama KM.Sabuk Nusantara 78 dengan panjang 68,5 meter, kapasitas penumpang 466 orang, kapasitas ruang muat 150 Ton.

b. 5 unit kapal perintis ukuran GT 1200 yang diberi nama KM.Sabuk Nusantara 99, KM. Sabuk Nusantara 100, KM.Sabuk Nusantara 101, KM.Sabuk Nusantara 102, dan KM.Sabuk Nusantara 103. Kapal perintis ukuran GT 1200 ini memiliki panjang 62,80 meter, kapasitas penumpang 400 orang, dan kapasitas ruang muat 50 Ton.

c. 2 unit kapal kontainer 100 Teus, yang diberi nama KM.Kendhaga Nusantara 7 dan KM.Kendhaga Nusantara 9, yang memiliki spesifikasi panjang 74,5 meter dan kapasitas kontainer 100 TEUs.

d. 1 unit kapal ternak yang diberi nama KM.Camara Nusantara 5 dengan spesifikasi panjang 69,78 meter, kapasitas ternak 500 ekor, kapasitas ruang muat 150 ton.

e. 1 unit Kapal Kelas I Kenavigasian KN. Masalembo yang memiliki tugas untuk menciptakan alur pelayaran yang aman dan perawatan Sarana Bantu Navigasi Pelayaran (SBNP). Adapun kapal kenavigasian ini memiliki panjang 60 meter, lebar 11 meter, dan kecepatan 15 knot. 
f. 6 unit kapal latih special purpose GT 1200. Kapal latih ini diharapkan dapat mempermudah para taruna untuk melaksanakan praktek berlayar serta dapat juga dapat dimanfaatkan untuk melayani rute pelayaran perintis.

Kapal latih yang dibangun untuk sekolah pelayaran yang berada dalam lingkungan BPSDMP Kementerian Perhubungan ini dibangun digalangan kapal dan industri dalam negeri oleh PT Steadfast Marine Pontianak. Pembangunan 6 kapal latih dimulai sejak Desember 2015 dan direncanakan selesai bertahap selama 2 tahun melalui APBN. Kehadiran enam kapal latih tersebut adalah sebagai upaya Kementerian Perhubungan dalam mendukung Nawacita sektor transportasi yang ditetapkan Presiden Republik Indonesia dan perwujudan fokus kerja Kemenhub tahun 2016 dalam meningkatkan keselamatan dan keamanan transportasi melalui peningkatan kualitas SDM Perhubungan dan sekolah pelayaran di Indonesia.

\section{Lokasi Penelitian}

Lokasi pengambilan data penelitian dilaksanakan di Kantor Kementerian Perhubungan, Kantor Kementerian Keuangan dan Pelabuhan dimana kapal negara dipoperasikan. Pelabuhan tersebut adalah Pelabuhan Bitung yang mewakili pelabuhan wilayah timur Indonesia dan Pelabuhan Batam yang mewakili pelabuhan di wilayah Barat Indonesia.

\section{Metode Penelitian}

Penelitian ini menggunakan metode kuantitatif deskriptif. Dalam konteks ini dilakukan deskripsi gejala atau fenomena yang berkaitan dengan pengawakan kapal negara khususnya yang berkaitan dengan Peraturan Direktur Jenderal Perhubungan Laut Nomor 103/3/13/DJPL18 Tentang Sertifikasi Keahlian dan Keterampilan Awak Kapal negara . 
Penelitian deskriptif adalah suatu metode penelitian yang ditujukan untuk menggambarkan fenomena-fenomena yang ada, yang berlangsung saat ini atau saat yang lampau. Penelitian ini tidak mengadakan pengubahan pada variabel-variabel bebas, tetapi menggambarkan suatu kondisi apa adanya. Penggambaran kondisi bisa individual atau menggunakan angka-angka. (Sukmadinata: 2006). Dalam penelitian ini berarti menggambarkan tingkat implementasi peraturan tentang sertifikasi awak kapal negara sesuai yang disyaratkan.

\section{Populasi Penelitian}

Menurut Warsito (1992), populasi adalah keseluruhan objek penelitian yang dapat terdiri dari manusia, gejala, nilai tes, atau peristiwa, sebagai sumber data yang memiliki karakteristik tertentu dalam suatu penelitian. Populasi yang penulis gunakan sebagai objek penelitian adalah awak Kapal negara pada level perwira yang mengoperasikan kapal negara dalam Kementerian Perhubungan dan Kementerian Keuangan sebanyak 558 orang. Kapal negara tersebut dikategorikan berdasarkan jenis dan fungsinya, yang terdiri dari kapal kelas I A dan I B, Kelas II, Kelas III dan kelas IV yang tersebar di seluruh Indonesia.

\section{a. Sampel Penelitian}

Sampel adalah sebagian atau wakil populasi yang diteliti, (Arikunto, 2002). Penetapan sampel yang digunakan dalam penelitian ini menggunakan jenis metode random sampling, yaitu sampel yang di acak dari para awak Kapal negara yang mengoperasikan kapal negara dalam Kementerian Perhubungan dan Kementerian Keuangan.

Dalam penelitian ini, sampel diteteapkan menggunakan rumus Slovin, yaitu sebuah rumus untuk menghitung jumlah sampel minimal apabila perilaku dari sebuah populasi tidak diketahui secara pasti. Rumus ini pertama kali diperkenalkan oleh Slovin pada tahun 
1960. Rumus Slovin ini biasa digunakan dalam penelitian survey dimana biasanya jumlah sampel besar sekali, sehingga diperlukan sebuah rumus untuk mendapatkan sampel yang jumlahnya sedikit tetapi dapat mewakili keseluruhan populasi. Adapun rumus Slovin adalah sebagai berikut :

$n=\frac{N}{1+N e^{2}}$

Dimana :

$\mathrm{n}=$ jumlah sampel minimal,

$\mathrm{N}=$ jumlah populasi

$\mathrm{e}=$ standar eror

Dengan demikian jumlah sampel dalam penelitian ini adalah sebanyak :

$n=\frac{932}{1+932 \times 0,05^{2}}=280$ awak kapal

Tabel 1. Kklasifikasi kapal negara dan awak kapal

\begin{tabular}{|c|c|}
\hline Kapal & Awak kapal \\
\hline kapal Kelas IA & 14 \\
\hline kapal Kelas IB & 2 \\
\hline kapal Kelas II & 34 \\
\hline kapal Kelas III & 80 \\
\hline kapal Kelas IV & 37 \\
\hline kapal Kelas V & 112 \\
\hline Jumlah & $\mathbf{2 8 0}$ \\
\hline
\end{tabular}

Sumber : Data diolah (2018)

\section{b. Instrumen Penelitian}

Instrumen yang digunakan untuk menjaring data dalam penelitian ini adalah instrument non tes dalam bentuk daftar observasi yang 
berhubungan dengan persentase kesesuaian antara sertifikat yang dimiliki oleh seorang awak kapal dengan jenis kapal yang dioperasikannya. Kesesuaian tersebut mengacu pada Peraturan Direktur Jenderal Perhubungan Laut Nomor 103/3/13/DJPL-18 Tentang Sertifikasi Keahlian dan Keterampilan Awak Kapal negara . Instrumen disusun mengacu pada indikator yang berhubungan dengan kesesuai sertifikat dengan jenis kapal yang dioperasikan. Indikator tersebut adalah sebagai berikut:

1. Jumlah kapal negara Kementerian Perhubungan

2. Jumlah kapal negara Kementerian Keuangan

3. Nama kapal

4. Jenis kapal dan DWT/KWH

5. Tingkat sertifikat Nahkoda

6. Jenis sertifikat Nahkoda (serifikat Kapal negara /Niaga)

7. Tingkat sertifikat Mualim I / II / III

8. Jenis setifikat Mualim I / II / III (serifikat Kapal negara /Niaga)

9. Tingkat sertifikat KKM

10. Jenis setifikat KKM (serifikat Kapal negara /Niaga)

11. Tingkat sertifikat Masinis I / II / III

12. Jenis setifikat Masinis I / II / III (serifikat Kapal negara /Niaga)

\section{c. Teknik Analisisis Data}

Teknik analisis data dalam penelitian ini menggunakan analisis kualitatif deskriptif. Menurut Sugiyono (2004) bahwa analisis deskriptif adalah pengujian yang digunakan untuk menganalisis data dengan cara mendeskripsikan atau menggambarkan data yang telah dikumpulkan sebagaimana adanya tanpa maksud membuat kesimpulan yang berlaku umum. Dalam penelitian ini analisis deskriptif dilakukan atas data hasil pengamatan yang dinyatakan dalam perhitungan persentase (\%), yaitu persentase jumlah awak kapal negara pada level perwira yang memiliki sertifikat kehlian dan 
ketermpian sesuai Peraturan Direktur Jenderal Perhubungan Laut Tentang Sertifikasi Keahlian dan Keterampilan Awak Kapal negara .

\section{d. Menghitung Persentase Capaian}

Untuk mengkaji permasalahan dalam penelitian ini maka dilakukan pengolahan data hasil score capaian responden yang didasarkan pada hasil dari masing-masing indikator yaitu jumlah kapal negara yang dioperasikan Kementerian Perhubungan dan Kementerian Keuangan dan jumlah awak kapal pada level perwira yang memiliki sertikat keahlian dan keterampilan yang sesuai Peraturan Direktur Jenderal Perhubungan Laut Tentang Sertifikasi Keahlian dan Keterampilan Awak Kapal Negara dengan formulasi rumus persentasi yang dikemukan oleh Purwanto (1991) sebagai berikut:

$\frac{\mathrm{F}}{\mathrm{N}} \times 100 \%$

Dimana:

$\mathrm{F}=$ Jumlah temuan dengan jawaban $\mathrm{YA}$

$\mathrm{N}=$ Jumlah indikator yang diamati

\section{e. Persentase Dan Kriteria Implementasi}

Setelah jawaban dianalisis menggunakan rumus persentase, selanjutnya disesuaikan dengan kriteria yang diadaptasi dari Sugiyono (2009) seperti tabel berikut ini:

Tabel 2. Rentang dan Kualifikasi Implementasi

\begin{tabular}{|c|c|l|}
\hline No. & Rentang Skor $(\%)$ & Kualifikasi \\
\hline 1 & $81-100$ & Sangat Terimplementasi \\
\hline 2 & $61-80$ & Cukup Terimplementasi \\
\hline 3 & $41-60$ & Terimplementasi \\
\hline 4 & $21-40$ & Tidak Terimplementasi \\
\hline 5 & $0-20$ & Sangat Tidak Terimplementasi \\
\hline
\end{tabular}




\section{f. Gambaran Kapal Negara Dan Kebutuhan Awak Kapal}

Perkembangan lingkungan strategis nasional dan internasional menuntut penyelenggaraan pelayaran yang sesuai dengan perkembangan ilmu pengetahuan dan teknologi, peran serta swasta dan persaingan usaha, otonomi daerah, dan akuntabilitas penyelenggara negara, dengan tetap mengutamakan keselamatan dan keamanan pelayaran. Berdasarkan Undang-Undang Nomor 17 tahun 2018 tentang Pelayaran disebutkan bahwa pelayaran adalah satu kesatuan sistem yang terdiri atas angkutan di perairan, kepelabuhanan, keselamatan dan keamanan serta perlindungan lingkungan maritim. Terminologi keselamatan dalam kegiatan pelayaran, mengacu pada istilah keselamatan dan keamanan, maka hal ini berarti bahwa keselamatan pelayaran adalah suatu keadaan terpenuhinya persyaratan keselamatan dan keamanan dalam pelayaran dan kepelabuhanan.

Terkait dengan kapal negara yang didefenisikan sebagai kapal milik negara yang digunakan oleh pemerintah yang diberi fungsi dan kewenangan sesuai dengan ketentuan peraturan perundangundangan untuk menegakkan hukum serta tugas-tugas lainnya, maka fungsi dan kewenangan yang dimiliki oleh kapal negara dipandang perlu memiliki awak kapal yang memenuhi standar sertifikasi yang ditetapkan pemerintah. Hal ini berarti bahwa pelayaran dengan awak kapal yang memenuhi standar hanya dapat dicapai jika kapal dioperasikan oleh awak) yang terdidik dan terlatih dengan baik. Badan Pengembangan Sumber Daya Manusia Perhubungan (BPSDMP) memegang peran strategis dalam upaya menciptakan sumber daya manusia berkualitas di bidang transportasi. Untuk pengawakan kapal negara, BPSDMP berupaya mencetak SDM berkualitas melalui peningkatan kualitas lembaga Diklat Pelayaran. Penelitian ini telah melakukan pengambilan data untuk memberi gambaran tentang kapal negara yang saat ini 
dioperasikan oleh kementerian lembaga. Khusus mengenai kapal patroli yang dioperasikan dalam Kementerian Perhubungan, Direktorat Jenderal Perhungan Laut, Kesatuan Penjagaan Laut dan Pantai, sebagai berikut:

Tabel 3. Rekapitulasi Jumlah Kapal Patroli KPLP dan Kebutuhan Awak Kapal

\begin{tabular}{|c|c|c|c|c|c|}
\hline Kelas Kapal & $\begin{array}{c}\text { Jumla } \\
\mathrm{h} \\
\text { Kapal }\end{array}$ & $\begin{array}{c}\text { Kebutuha } \\
\mathrm{n}\end{array}$ & $\begin{array}{c}\text { Existin } \\
\mathrm{g}\end{array}$ & $\begin{array}{c}\text { Kekuranga } \\
\mathrm{n}\end{array}$ & $\begin{array}{c}\text { Persentas } \\
\text { Kekuranga } \\
\mathrm{n}\end{array}$ \\
\hline $\begin{array}{c}\text { Kapal Kelas } \\
\text { I-A }\end{array}$ & 1 & 41 & 15 & 26 & 63 \\
\hline $\begin{array}{c}\text { Kapal Kelas } \\
\text { I-B }\end{array}$ & 6 & 204 & 104 & 100 & 49 \\
\hline KNP KIs II & 15 & 390 & 178 & 212 & 54 \\
\hline KNP Kls III & 59 & 1003 & 342 & 661 & 66 \\
\hline KNP KIs IV & 69 & 483 & 171 & 312 & 65 \\
\hline KNP Kls V & 245 & 735 & 643 & 92 & 13 \\
\hline Total & 395 & 2856 & 1453 & 1403 & 49 \\
\hline
\end{tabular}

Sumber: Data diolah, 2018

Berdasarkan hasil olah data pada tabel 4.1 terlihat jumlah kapal yag saat ini dioprasikan sebagai kapal negara yang bertugas melaksanakan patrol. Data dari Kemeterian Perhubungan, Direktorat Jenderal Perhubungan Laut diketahui terdapat 1 kapal jenis Kapal Kelas I-A. Untuk mengoperasikannya dibutuhkan 41 awak kapal, namun yang tersedia hanya 15 awak kapal atau terdapat kekurangan sebesar $63 \%$.

Pada table 4.1. diketahui terdapat 6 kapal Kapal kelas I-B. Untuk mengoperasikannya seluruh kapal tersebut dibutuhkan 204 awak 
kapal, namun yang tersedia hanya 104 awak kapal atau terdapat kekurangan sebesar $49 \%$.

Untuk Kapal kelas II, terdapat 15 kapal. Untuk mengoperasikannya seluruh kapal tersebut dibutuhkan 178 awak kapal, namun yang tersedia hanya 390 awak kapal atau terdapat kekurangan sebesar $54 \%$.

Untuk Kapal kelas III, terdapat 59 kapal. Untuk mengoperasikannya seluruh kapal tersebut dibutuhkan 342 awak kapal, namun yang tersedia hanya 1003 awak kapal atau terdapat kekurangan sebesar $66 \%$.

Untuk Kapal kelas IV, terdapat 69 kapal. Untuk mengoperasikannya seluruh kapal tersebut dibutuhkan 171 awak kapal, namun yang tersedia hanya 483 awak kapal atau terdapat kekurangan sebesar $65 \%$.

Untuk Kapal kelas V, terdapat 245 kapal. Untuk mengoperasikannya seluruh kapal tersebut dibutuhkan 643 awak kapal, namun yang tersedia hanya 735 awak kapal atau terdapat kekurangan sebesar $13 \%$.

Apabila dilihat secara keseluruhan kelas KNP maka kekurangan awak kapal adalah sebesar 49\% atau sama dengan 1403 awak kapal. Kekurangan atau kebutuhan awak kapal terbesar menurut kelas kapal ada pada KNP kelas III dengan persentase kebutuhan sebesar $66 \%$ atau sama dengan 661 awak kapal. Selanjutnya terendah berada pada KNP kelas $V$ sebesar $13 \%$ atau sama dengan 92 awak kapal.

\section{g. Deskripsi Kesesuaian Sertifikat}

Berdasarkan Peraturan Direktur Jenderal Perhubungan Laut Nomor HK.103/3/13/DJPL-15 tentang Spesifikasi Keahlian dan Keterampilan awak Kapal Negara, maka yang dimaksud kapal negara adalah kapal milik negara digunakan oleh instansi pemerintah tertentu yang diberi fungsi dan kewenangan sesuai 
dengan ketentuan peraturan perundang-undangan untuk menegakkan hukum serta tugas-tugas pemerintah lainnya. Untuk itu semua awak kapal negara perlu memiliki sertifikat kompetensi dan sertifikat keterampilan untuk membantu terlaksananya tujuan dan fungsi kapal negara tersebut. Sertifikat kompetensi adalah sertifikat yang diterbitkan kepada perwira kapal negara sebagai bukti bahwa pemilik telah memiliki kompetensi yang dipersyaratkan untuk kapal negara dan kewenangan jabatan kapal negara. Sedangkan sertifikat keterampilan kapal negara adalah sertifikat yang diterbitkan kepada awak kapal negara sebagai bukti bahwa pemilik telah memiliki keterampilan tertentu yang diperlukan dalam menjalankan tugasnya pada kapal negara.

Penelitian ini dilakukan terhadap perwira kapal negara yang terdiri atas nakhoda, Mualim I, Mualim II dan Mualim III, KKM dan masinis I, II dan III. Sesuai dengan hasil penelitian diperoleh data kondisi ketersediaan awak kapal dan kompetensi keahlian dan keterampilan berdasakan kelas KNP sebai berikut:

Tabel 4. Kesesuaian Awak Kapal dan Kompetensinya pada KNP Sesuai Jenis Kapal

\begin{tabular}{|c|c|c|c|c|c|c|}
\hline $\begin{array}{l}\text { Jenis } \\
\text { Kapal }\end{array}$ & $\begin{array}{l}\text { Awak } \\
\text { kapal }\end{array}$ & $\begin{array}{c}\text { Sampe } \\
\text { I } \\
\text { Terpili } \\
\text { h }\end{array}$ & $\begin{array}{c}\text { Tidak } \\
\text { Sesuai } \\
\text { Kualifikas } \\
\text { i }\end{array}$ & $\begin{array}{c}\text { Sesuai } \\
\text { Kualifikas } \\
\text { i }\end{array}$ & $\begin{array}{c}\text { Persentas } \\
\text { e Tidak } \\
\text { Sesuai }\end{array}$ & $\begin{array}{c}\text { Persentas } \\
\text { e Sesuai } \\
\text { Kualifikasi }\end{array}$ \\
\hline $\begin{array}{c}\text { Kelas } \\
\text { IA }\end{array}$ & 48 & 14 & 9 & 5 & 65 & 35 \\
\hline $\begin{array}{c}\text { Kelas } \\
\text { IB }\end{array}$ & 8 & 2 & 1 & 1 & 50 & 50 \\
\hline Kelas II & 113 & 34 & 26 & 8 & 77 & 23 \\
\hline $\begin{array}{c}\text { Kelas } \\
\text { III }\end{array}$ & 266 & 80 & 35 & 45 & 56 & 44 \\
\hline
\end{tabular}




\begin{tabular}{|c|c|c|c|c|c|c|}
$\begin{array}{c}\text { Kelas } \\
\text { IV }\end{array}$ & 123 & 37 & 19 & 18 & 51 & 49 \\
Kelas V & 374 & 112 & 73 & 39 & 65 & 35 \\
\hline & 932 & 280 & 163 & 116 & & \\
\hline
\end{tabular}

Sumber : Data diolah (2018)

Berdasarkan tabel 4.2. dengan menggunakan data sampel terpilih diketahui untuk jenis kapal kelas IA, terdapat 14 awak kapal, 9 awak kapal yang sertifikatnya tidak sesuai aturan sertifikasi dan hanya 5 orang awak kapal yang sesuai aturan sertifikasi. Jika dipersentasekan maka 65\% awak kapal kapal negara memiliki sertifikat yang tidak sesuai dengan aturan sertifikasi, atau hanya $35 \%$ yang sesuai aturan sertifikasi.

Selanjutnya untuk jenis kapal kelas IB terpilih 2 sampel perwira awak kapal negara, dengan 1 orang awak kapal yang tidak sesuai kualifikasi dan 1 orang awak kapal yang memenuhi kualifikasi, atau $50 \%$ sesuai aturan sertifikasi dan $50 \%$ sisanya tidak sesuai aturan sertifikasi.

Untuk jenis kapal kelas II dari 34 awak kapal kapal negara yang terpilih sebagai sampel, ada 26 atau sebesar $77 \%$ awak kapal kapal negara yang tidak sesuai dengan kualifikasi, dan hanya 8 atau sebesar $23 \%$ awak kapal kapal negara yang sesuai kualifikasi.

Kemudian untuk kapal kelas III, ada 80 sampel awak kapal yang dipilih dengan kondisi 45 orang awak kapal yang tidak sesuai aturan sertifikasi dan hanya 35 oang awak kapal yang memenuhi aturan sertifikasi, dengan kata lain jika dinyatakan dalam perentase ada $56 \%$ awak kapal yang tidak memenuhi aturan sertifikasi dan $44 \%$ awak kapal yang sertifikatnya memenuhi aturan sertifikasi.

Kondisi awak kapal negara Kelas IV dengan sampel awak kapal sebanyak 37 orang terlihat bahwa ada 19 orang awak kapal yang tidak memenuhi aturan sertifikasi dan 18 orang awak kapal negara 
yang tidak memenuhi aturan sertifikasi atau jika dinyatakan dalam persentase ada $51 \%$ yang tidak memenuhi aturan sertifikasi dan $49 \%$ yang srtifikatnya memenuhi aturan sertifikasi.

Pada kapal negara Kelas V jumlah sampel terpilih sebanyak 112 awak kapal kapal negara dengan keadaan 73 atau 65\% awak kapal yang tidak memenuhi aturan sertifikasi sedang yang memenuhi aturan sertifikasi adalah sebanyak 39 atau sebanyak 35\% awak kapal kapal.

Berdasarkan table 4.1. diatas diketahui bahwa dari 932 awak kapal pada kapal jenis patroli hanya terdapat $39.3 \%$ atau hanya 152 awak kapal yang memiliki sertifikat sesuai, sedang $66.7 \%$ awak kapal atau sama dengan 780 awak kapal memiliki sertifikat yang tidak sesuai dengan ketentan sertifikais awak kapal negara.

Selanjutnya untuk mengetahui implementasi Peraturan Direktur Jenderal Perhubungan Laut Nomor HK.103/3/13/DJPL-15 tentang Spesifikasi Keahlian dan Keterampilan awak Kapal Negara maka berdasarkan data di atas dapat dilihat pada tabel berikut ini :

Tabel 5. Implementasi Peraturan DJPL Nomor HK.103/3/13/DJPL-15 tentang Spesifikasi Keahlian dan Keterampilan Anak Buah Kapal Negara

\begin{tabular}{|c|c|c|}
\hline Jenis Kapal & $\begin{array}{c}\text { Persentase } \\
\text { Sesuai } \\
\text { Kualifikasi }\end{array}$ & Kriteria Implementasi \\
\hline Kelas IA & 35 & Tidak terimplementasi \\
Kelas IB & 50 & Terimplementasi \\
Kelas II & 23 & Tidak terimplementasi \\
Kelas III & 44 & Terimplementasi \\
Kelas IV & 49 & Terimplementasi \\
Kelas V & 35 & Tidak Terimplementasi \\
\hline
\end{tabular}

Sumber : Data diolah (2018) 
Berdasarkan hasil pengolahan data pada table 4.3. di atas diketahui bahwa implementasi Implementasi Peraturan Direktur Jenderal Perhubungan Laut tentang Spesifikasi Keahlian dan Keterampilan awak Kapal Negara yang menjadi objek penelitian untuk Kapal Kelas I-A adalah sebesar 35\% atau berada dalam kategori Tidak Terimplementasi. Hal ini juga menggambarkan bahwa hanya $35 \%$ dari awak kapal negara yang memiliki sertifikat sesuai dengan jenis kapal yang dioperasikannya.

Pada Kapal Kelas I-B diketahui bahwa implementasi peraturan tentang srtifikasi kanal negara adalah sebesar $50 \%$ atau berada dalam kategori terimplementasi. Hal ini juga menggambarkan bahwa $50 \%$ dari awak kapal negara pada Kapal Kelas I-B yang memiliki sertifikat sesuai dengan kapal yang dioperasikannya.

Pada Kapal Kelas II diketahui bahwa implementasi peraturan tentang srtifikasi kanal negara adalah sebesar $23 \%$ atau berada dalam kategori Tidak Terimplementasi. Hal ini juga menggambarkan bahwa hanya $23 \%$ dari awak kapal negara pada Kapal Kelas I-B yang memiliki sertifikat sesuai dengan kapal yang dioperasikannya.

Pada Kapal Kelas III diketahui bahwa implementasi peraturan tentang srtifikasi kanal negara adalah sebesar $44 \%$ atau berada dalam kategori Terimplementasi. Hal ini juga menggambarkan bahwa hanya $44 \%$ dari awak kapal negara pada Kapal Kelas I-B yang memiliki sertifikat sesuai dengan kapal yang dioperasikannya.

Pada Kapal Kelas IV diketahui bahwa implementasi peraturan tentang srtifikasi kanal negara adalah sebesar $49 \%$ atau berada dalam kategori Terimplementasi. Hal ini juga menggambarkan bahwa hanya $49 \%$ dari awak kapal negara pada Kapal Kelas I-B yang memiliki sertifikat sesuai dengan kapal yang dioperasikannya. Pada Kapal Kelas $\mathrm{V}$ diketahui bahwa implementasi peraturan tentang srtifikasi kanal negara adalah sebesar $35 \%$ atau berada dalam kategori Tidak Terimplementasi. Hal ini juga menggambarkan 
bahwa hanya $35 \%$ dari awak kapal negara pada Kapal Kelas I-B yang memiliki sertifikat sesuai dengan kapal yang dioperasikannya.

\section{Simpulan}

Jumlah kapal negara yang saat ini dioperasikan hanya oleh Kementerian terkait hanya 50\% atau separuh dari jumlah seluruh kapal yang dibutuhkan. Kondisi ini tentu berdampak pada kinerja layanan kapal negara. Bahwa hanya $39.3 \%$ anak buah kapal negara yang memiliki sertifikat kompetensi dan profesiensi yang sesuai dengan aturan sertifikasi pada Peraturan Direktur Jenderal Perhubungan Laut Nomor HK.103/3/13/DJPL-15. Kondisi ini sekaligus mengindikasikan besarnya kebutuhan anak buah kapal negara untuk mengikuti pendidikan dan pelatihan yang sesuai dengan kapal yang operasikannya.

\section{Saran}

Disarankan untuk anak buah kapal Negara untuk diikutkan pelatihan agarmemiliki sertifikat kompetensi dan profisiensi yang sesuai dengan aturansertifikasi pada peraturan Direktur Jenderal Perhubungan Laut Nomor HK.103/3/13/DJPL-15.

\section{DAFTAR PUSTAKA}

[1]. Arikunto, S. (2002). Metode Penelitian, Jakarta: PT. Rineka Cipta. Indonesia ferry (2017). Profile. https://www.indonesiaferry.co.id/ profil perusahaan

Diakses pada tanggal 25 Maret 2018.

[2]. Kementerian Perhubungan (2008). Undang-Undang Nomor 17 Tahun 2008 Tentang Pelayaran. 
[3]. Kementerian Perhubungan (2013). Peraturan Menteri Perhubungan Republik Indonesia Nomor PM 70 Tahun 2013 Tentang Pendidikan dan Pelatihan, Sertifikasi Serta Dinas Jaga Pelaut.

[4]. Kementerian Perhubungan (2015). Peraturan Direktur Jenderal Perhubungan Laut Nomor 103/3/13/DJPL-15 Tentang Sertifikasi Keahlian dan Keterampilan Awak Kapal Negara.

[5]. Mardalis (2008). Metode Penelitian Suatu Pendekatan Proposal. Jakarta: Bumi Aksara

[6]. Pelni (2017). Daftar Nama Kapal Pelni Berlayar Di Indonesia http://www.seputarkapal.com/2016/06/daftar-nama-kapal-pelni. html Diakses pada tanggal 25 Maret 2018.

[7]. Peraturan Direktur Jenderal Perhubungan Laut Nomor HK.103/3/13/DJPL-15 Tentang Sertifikasi Keahlian dan Keterampilan Awak Kapal negara.

[8]. Peraturan Menteri Perhubungan Republik Indonesia Nomor PM 70

Tahun 2013 Tentang Pendidikan dan Pelatihan, Sertifikasi Serta Dinas Jaga Pelaut

[9]. Purwanto, N. (1991). Administrasi dan Supervisi Pendidikan. Bandung: Alfabeta.

[10]. Sugiyono (2009) Metode Penelitian Kuantitatif dan R\&D. Bandung: Alfabeta.

[11]. Sukmadinata (2006). Penelitian Kualitatif untuk IImu-IImu Kemanusiaan dan. Budaya. Jakarta: Cangara.

[12]. Warsito, H. (1992). Pengantar Metodologi Penelitian. Jakarta: Gramedia, Pustaka Utama

[13]. Widayat, A. (2002). Metode Penelitian: Reabilitas dan Validitas. Yogyakarta: Gamma

[14]. Widayat, A. (2004). Metode Penelitian Pemasaran. Malang: CV. Cahaya Press. 